\title{
Title: Architecture, symbolic capital and elite mobilizations: The case of the Royal Bank of Scotland corporate campus
}

Authors:

Dr Ron Kerr, University of Edinburgh Business School, 29 Buccleuch Place, Edinburgh EH8 9JS. Email: ron.kerr@ed.ac.uk

Dr Sarah Robinson, University of Leicester School of Management, Ken Edwards Building, University of Leicester, University Road, Leicester, LE1 7RH. Email: sr307@le.ac.uk

\section{Introduction}

In this paper we apply the conceptual framework of Pierre Bourdieu, in particular forms of capital, social fields, the field of power, and modes of domination, to demonstrate how the study of a symbolically powerful building can provide insights into what are often opaque elite interactions. In order to do this, we focus on the corporate campus headquarters of a powerful financial institution, the Royal Bank of Scotland (RBS). RBS, we argue, constitutes a 'special case of what is possible' (Bourdieu 1998:2) that has a wide social significance, given the power of banking and finance in Scotland, as elsewhere, before 2009, and in particular in the capital city Edinburgh (Fessy and McIntosh 2008). Indeed, by 2009 RBS was the largest bank in the world with assets of over £2 trillion, before collapsing into state ownership in 2009 with losses of £24.1bn (Treasury Committee 2012): a rise and fall that has subsequently been studied from various angles, with a particular focus on the role of Fred Goodwin, CEO from 2001-2009 (see Martin 2013, Fraser 2014 for narrative accounts of the bank's expansion and collapse; for a theoretical perspective, see Kerr and Robinson 2011, 2012)

In this present paper, we return to and extend these studies of the Scottish elite through a methodology in which we use a corporate building as a key to understand the dynamic processes by means of which the new headquarters and its layout came to affirm the economic and symbolic power of the bank and its leadership. In tracking the progress of the building from its conception in 2001 as the 'vision' of its (then) new CEO, Fred Goodwin, to its official opening in 2005, when the campus was seen as 'the 
crowning glory for the Royal's rise to world recognition' (Scotsman 2005), we are able to shed light on how different social fields (financial, political, bureaucratic, architectural) and the elites of those fields, interacted dynamically, thus demonstrating the important role of architecture and corporate space in circuits of capital, especially in terms of the conversion of economic capital into symbolic capital. We also touch on what the story of the building's design and construction might retrospectively reveal in relation to the bank's collapse.

We pose the following questions. What is the relationship between corporate space and the field of power? What role does a corporate building play in circuits of capital conversion? What does this case tell us about the role of architecture in elite mobilisations? In addressing these questions, we contribute to the organizational literature on elites: e.g., Harvey and Maclean (2008); Savage and Williams (2008); Williams and Filippakou (2009), Zald and Lounsbury (2010), Maclean, Harvey and Chia (2010), Kerr and Robinson (2012), Maclean, Harvey and Kling (2014). However, within this growing stream of literature, there is a notable absence of contributions on inter-elite mobilisations, in particular in relation to space and architecture. This is a challenge we address in this study by employing and extending the work of Bourdieu on space, symbolic power and domination (e.g. Bourdieu 1976, 1980, 1993), and Bourdieu-inspired work on architecture and power (e.g., Pinto 1991, Dovey 1999, Lipstadt 2003).

We also respond to calls by, e.g., Emirbayer and Johnson (2008), Swartz (2008), Kerr and Robinson (2009, 2012), and Golsorkhi, Leca, Lounsbury and Ramirez (2009), to extend the use of Bourdieu's conceptual framework in organization studies, by identifying and theorising the role of corporate space in inter-elite dynamics and circuits of capital conversion. This approach, we argue, provides a methodological lever which could be applied to other symbolically important buildings in order to understand the nature and role of inter-field interactions in their inception and realisation.

The paper is organized as follows: first, we review Bourdieusian perspectives on architecture, space and power before introducing the main concepts that we use in our analysis. We then discuss our 
methodology and data, followed by the main analysis sections under the headings: circuits of capital conversion; capital objectified; hierarchy and physical space; distinction and cultural dominance; and RBS and the field of power in Scotland. A discussion of what we have learned from applying Bourdieu's concepts to this empirical case is then followed by our conclusions.

\section{Architecture, space, and power: Bourdieusian perspectives}

Calls to extend Bourdieusian approaches in critical management and organization studies have led to a growing literature on, for example, leadership (e.g., Kerr and Robinson 2011), accounting (e.g., Carter and Spence 2014), elites (e.g., Maclean et al. 2014), management education (e.g., Vaara and Faÿ 2012), and management control (e.g., Kamoche, Kannan and Siebers 2014). As yet, however, there has been little focus by Bourdieusian organizational scholars on issues of architecture, organizations and space in relation to elite power. This comparative absence is surprising, given Bourdieu's own interest in the symbolic uses of built space that originate in the ethnographic/anthropological studies in Algeria in the 1950s (La maison ou le monde renverseé, Bourdieu 1972 ${ }^{\mathrm{i}}$ ) and in his own region of the Béarn (Célibat et condition paysanne, Bourdieu 1962; Le bal des célibataires, Bourdieu 2002).

Again, through an interest in architectural history, Bourdieu further developed an understanding of the connection between symbolically powerful buildings and social power. In particular, in his postface to his own translation of Panofsky’s 'Gothic architecture and scholastic thought' (Bourdieu 1967), Bourdieu theorises how (according to Panofsky), the dominant scholastic habitus of Aquinas and his contemporaries was, through the efforts of a powerful patron, Abbot Suger, in co-operation with the anonymous architect of St-Denis, translated into the awe-inspiring intellectual and material order of the great 12th Century Gothic cathedrals. This interest in the analysis of space in relation to social power and hierarchy continued to be part of Bourdieu's research programme: Raymond Williams for example being invited to deliver lectures on the $18^{\text {th }}$ Century English country house to Bourdieu's research group. These lectures were published in Bourdieu's journal, Actes de la recherche en sciences sociales (Williams 1977; Chamboredon 1977) and focus on the relation between designed 
space and the reproduction of class power: on the contradiction between what is shown in the beautifully landscaped parks of the country houses (the 'pleasant perspectives') and what is concealed (all signs of productive labour).

Building on these studies, Bourdieu (1990, 1991a, 1993), further developed a conceptual framework that can be used to analyze the effects of, and connections between, social and symbolic power and physical space. This approach to the role of space, particularly suited to analyses of the production and reproduction of social inequalities, has been picked up in urban studies and urban sociology (by, e.g., Séliminanowski 2009; Garbin and Millington 2012) to address issues of stigmatised social and physical spaces (Wacquant 2005a, 2006; Sayad, 1995; Beaud and Pialoux, 1999; Delsaut, 1999), and also in a series of studies by Michel Pinçon ${ }^{\mathrm{ii}}$ and Monique Pinçon-Charlot on the reproduction and defence of elite spaces by the French haute bourgeoisie. This is accomplished by, amongst other strategies, leveraging local and national government initiatives, such as preservation societies and regional parks (Pinçon and Pinçon-Charlot 2001, 2005, 2007). Taken together, these studies of stigmatised and elite spaces allow us to elaborate a Bourdieusian theorisation of the relationality of space in creating stigmatised and elite social groups.

In addition, a growing number of studies apply Bourdieu's field theory to architecture (see Jones 2009). From this perspective, architecture is understood as a social field: 'an autonomous universe, a kind of arena in which people play a game which has certain rules which are different from those of the game that is played in the adjacent space' (Bourdieu, 1991b:2). Field studies of architecture include (1) those that focus on the internal constitution of fields and field positions and (2) those that focus on interactions between fields. The first group identify opposing field positions within a national architectural field, what Bourdieu calls pôles of cultural production (Bourdieu 1992). So, for the French architectural field, Biau (1998) identifies a constituting tension between the logic of doing business (faire des affaires) and the logic of doing the work for its own sake or as artistic creativity (realiser des oeuvres): see also Violeau (1999) and Montlibert (1995). Similarly, for the architectural field in the UK, Stevens (1998) identifies two opposing poles, one a subfield of relatively restricted 
production, constituted by dominant architects who are 'producers of legitimate architectural form', while the other is constituted by a 'mass subfield' of dominated architects 'imitating form without understanding meaning' (in the eyes of the restricted field) (Stevens 1988:88; and see also Fowler and Wilson 2004).

On the other hand, field interaction studies focus on the mutual reinforcement of field positions between elites of different fields. For example, Lipstadt (2003), in her analysis of architectural competitions in Renaissance Italy, identifies how the relationship between client and architect involves a 'dialectic of distinction' (Lipstadt 2003: 402-403), a mutual reinforcement of prestige that, she argues, can also be seen to operate in the contemporary world in the public competitions set up to judge prestigious civic or corporate commissions. In this way, architects at the restricted pole (that of 'art for art's sake') are constituted as a ‘consecrated elite’ (Bourdieu 1986) - we might call them ‘starchitects' - who are nevertheless entirely dependent on state or corporate clients, or on commissions from the independently wealthy (Jones 2011). This dialectic between elites also means that, according to Stevens, architects play an ideological role in 'producing those parts of the built environment that the dominant classes use to justify their domination of the social order ... buildings of power, buildings of state, buildings of worship, buildings to awe and impress' (Stevens, 1998:88).

Drawing on Bourdieu and Hillier and Hanson's (1984) 'social logic of space’, Dovey (1999) addresses the day-to-day construction and reproduction of social domination in and by symbolically powerful buildings. He does this through a series of studies of building designs in relation to political power, including Nazi architecture, the Forbidden City in Beijing, the Houses of Parliament in London, and building types such as corporate towers and shopping malls. In so doing, Dovey takes as a critical starting point Bourdieu's comment that 'the most successful ideological effects are those that have no words, and ask no more than complicitous silence' (Bourdieu 1977:188). To this Dovey adds, 'the ideological effects of built form lie largely in this thoughtless yet necessary complicity' (Dovey 1999:2), thus emphasising the power of the 'silent complicity' of architecture and the 'taken for granted' nature of domination with regard to political and economic projects such as corporate tower 
blocks. However, for Dovey, a building's symbolic capital is not so much created as 'moved around from one temporary landmark to another' (1999:4): that is, a building's symbolic capital is not inherent in the building as such, but arises from the context in which it is created. Similarly, for Louis Pinto, one of Bourdieu's associates, the competing cultural and political visions involved in planning the state-funded Beaubourg Centre in Paris made it 'inconceivable to disassociate architectural representations from the ideological context within which they take their meaning’ (Pinto 1991:98, our translation). In this fascinating analysis of a symbolically important building, Pinto goes on to show how the 'monument appears as a stake (enjeu) in a struggle between groups with their specific material and symbolic interests', including politicians, modernist and postmodernist architects, and members of the French cultural elite (Pinto 1991:114).

In summary, the literature reviewed in this section gives us clear directions to pursue in relation to the analysis of corporate buildings. By bringing Bourdieu's concepts together (social fields and their interactions, forms of capital, power as modes of domination, symbolic space, and a building as a stake in symbolic struggles), we are able to apply them through the development of a theoreticallyinformed case study of a corporate building from conception to realisation, identifying changes in usage/perception over time, and showing how it counts as symbolic capital in the power struggles of its time and place. Through our analysis of fields, their dynamic interactions and circuits of capital conversion, we contribute both to Bourdieusian critical organizational theory and to the study of buildings, corporate power and social elites. How the Bourdieusian concepts that we use in this study fit together analytically is discussed in the section which follows.

\section{Forms of capital, fields of power and domination}

In dealing with issues of organizations, power and space in relation to the RBS corporate campus, we utilise a number of Bourdieusian concepts. Given that we have already introduced some of these in the previous section, this section serves as a brief summary of the key concepts that we operationalise in our analysis: social fields, the field of power, forms of capital, habitus, and modes of domination (for a systematic exposition of Bourdieu’s framework, see Swartz 1997, 2013). 
The concept of a social field indicates ‘a kind of arena in which people play a game which has certain rules... which are different from those of the game that is played in the adjacent space' (Bourdieu 1991b:215), constituting 'a set of objective, historical relations between positions anchored in certain forms of power (or capital)' (Bourdieu and Wacquant 1992:16). Fields are also 'spaces of relationships' between dominant and dominated groups: groups occupying structurally similar positions in different fields can be said to be homologous (Bourdieu 1985). Fields relevant to our present study include the architectural field, the field of banking and finance, the bureaucratic field, and the political field in Scotland. We also include the 'meta-concept' of the field of power (Bourdieu 1990, 2012), which explains how 'power is concentrated in definite institutional sectors and in given zones of social space; the field of power (being) precisely the arena...where the relative value of diverse species of power is contested and adjudicated' (Wacquant, 2005b: 44). In this formulation, Bourdieu (as summarized by Wacquant) is thinking about power at the level of the state. But a large organization can also be seen as a social field (see 'l'entreprise comme champ', Bourdieu 2000: 252254). Understood this way, it is possible to analyse 'the internal government of the firm' including 'the dispositions of the dirigeants operating within the constraints of the field of power within the firm' and 'its hierarchy, the extent of bureaucratic differentiation and the role of different forms of capital' (Bourdieu 2000:252, our translation).

However, social agents entering into or situated in a particular field bring with them or acquire specific forms of capital in order to negotiate and establish their positions. These forms of capital, as outlined in Bourdieu (1986) are: economic capital, cultural capital (knowledge, skills and other cultural acquisitions, as exemplified by educational or technical qualifications), and social capital (the networks a person can draw on as a resource). Cultural capital, which can be incorporated in persons as habitus (Wacquant, 2002) and reified as physical objects, such as buildings, may endow the bearer with the ability to realise a vision of the world, impose it on others and have it accepted as natural (Bourdieu 2012). 
In addition to these three forms, however, Bourdieu also utilises a fourth form, symbolic capital (a concept that seems to predate economic and social capital in Bourdieu's oeuvre: see, e.g., Bourdieu 1972). This fourth form of capital can be understood as operating either as an additional form referring to legitimation and accumulated prestige and honour (as in, e.g., Bourdieu 1994) or as a sort of meta-capital that 'obtains from the successful use of other capitals' (Swartz 1997: 92). In this second sense, as Bourdieu explains in Méditations Pascaliennes, symbolic capital operates as a way of capturing 'the symbolic effects of capital' (Bourdieu 1997: 285).

So, given that forms of capital (economic, cultural, social) are recognised as legitimate within particular fields (financial, political, etc.), we propose to follow the Bourdieu of Méditations in taking symbolic capital as a way of thinking how forms of capital can be converted into power across fields - and in particular how they are convertible in fields of power: the state, for example (Bourdieu 1994: 9).

For Bourdieu (following Weber), acceptance of the legitimacy of an established social order requires the submission of the dominated, either through force or through acceptance of the arbitrary social order as natural (Bourdieu, 1991b). In order to conceptualise this, Bourdieu (1976 ${ }^{\mathrm{iii}}$ ) distinguishes two ‘elementary forms of domination': first, economic/material violence (or 'overt violence', see Bourdieu, 1980: 217-18) and, second, symbolic violence. The first of these involves the 'direct, daily, personal work' of domination (Bourdieu 1976: 190). However, this more overt mode of violence is in the long run less economical than the 'softer', 'sweeter' (douce ${ }^{i v}$ ), or more seductive strategies of symbolic violence (Bourdieu 1976:191; Robinson and Kerr 2009), that is, the imposition of and misrecognition of arbitrary power relations (symbolic categories such as class, race, gender) as natural and legitimate (Bourdieu 1976:122).

We have shown elsewhere the dynamic by which, under pressure from globalising neoliberalism, local elites and organizations are de-localising, becoming European, then global, at least in intention, while retaining a local identity (Kerr and Robinson 2011, 2012). In the present study we consider the role of the new headquarters building in relation to (a) the organization as field (RBS); (b) the 
European field of banking leaders (Goodwin as part of the UK banking elite); (c) the local bureaucratic and political fields (the city's planners and elected councilors); and (d) the national political field (Scotland's devolved governments). In this way we aim to show how the building counted as symbolic capital in different fields while serving to perpetuate modes of domination within the social and physical spaces of the organization itself (Robinson and Kerr 2009).

\section{Methodology and data}

This study follows a Bourdieusian approach to methodology in presenting a theoretically-framed and historically-situated case, in which Bourdieu's concepts are used to engage with the empirical world (Bourdieu 1998; Leander 2008). That is, we apply the concepts to the empirical data in order to make sense of the world; and in turn, we go back from the empirical to the concepts to see how the concepts might be extended or modified in light of the empirical data. Given that in this approach 'the context defines what is relevant', as a logical consequence 'there can be no firm guidelines to what kind of material is useful for the analysis' (Leander 2008:12) and, therefore, 'the exact evidence that needs to be mustered will vary' and 'depending on their exact research focus, studies include things as diverse as statistical data, biographical information, photographical evidence, works of art or literature, analysis of classical texts, archival research, public speeches, newspaper clippings, or interviews' (Leander 2008: 12). This approach also responds to the difficulty faced by researchers in studying relatively closed elite groups, as noted by, e.g., Bowman, Froud, Johal, Moran and Williams (2013).

In collecting data, we started with newspaper accounts and online photos of the campus and drew on official documents and other evidence, to build up an increasingly plausible account of the conception, construction and social context of the campus. Data included publically available documents, e.g., local and Scottish government reports on the 'scotgov' website and planning documents which we accessed either online or at the City of Edinburgh Council Planning Department archives in Edinburgh. Of particular relevance were: (1) Planning Brief, Gogarburn, 1998, (2) Outline Planning Brief, Gogarburn, 2002; (3) RBS ‘Global Headquarters Economic Position Statement’ 2002; (4) City of Edinburgh Council (CEC) Combined Strategic Construction Response, 2002. 
We also drew on Parliamentary reports: FSA (Financial Services Authority) Enquiry (2011); House of Commons Treasury Committee (2012-2013); Scottish Affairs Committee (2009); Scottish Parliament Economy, Energy and Tourism Committee (2009-2012); and Parliamentary Commission on Banking Standards ('Tyrie Commission’, 2012-2013).

We consulted the web-based archives of the architects and project managers: Michael Laird Architects (MLA) at http://www.michaellaird.co.uk/, and MACE at http://www.macegroup.com/. In addition, we consulted RBS's annual reports at http://www.northcote.co.uk/?SDL=NI02418; plus other official documents, news releases, etc. We also compiled a corpus of newspaper reports and commentaries from specialist publications, and identified other web sources that referenced life at Gogarburn. The website of the Royal Commission on the Ancient and Historical Monuments of Scotland (Canmore) at canmore.rcahms.gov.uk provided a fascinating series of aerial photographs and other historical data tracing the history of the development of the site.

For the history of the corporate campus typology we drew on exhibition catalogues of architects Eero Saarinen (Pelkonen and Albrecht 2006) and Kevin Roche (Pelkonen 2011) and interviews with Roche (in Dal Co 1984) and with Gordon Bunshaft of SOM (Bunshaft 1990). For information on corporate HQs that influenced the design of the Gogarburn campus, e.g., the BA Waterside headquarters, we consulted The National Archives website: http://webarchive.nationalarchives.gov.uk.

Having built up a picture of the campus and its construction in its socio-historical context, we then conducted interviews (1) with informants involved in the design and construction of the campus (Interviews a and b) and (2) with former RBS employees who provided information supporting published claims (see Malone 2009, Martin 2013; Fraser 2014) about the way the building was furnished and operated (Interviews c, d, e, f). Recent publications on RBS by Martin (2013) and Fraser (2014), who gather together a wealth of empirical evidence, provided rich sources of data on the bank's growth and collapse. We have respected requests by informants by not identifying individual interviewees: these requests seem to confirm the continued domination of Goodwin-era 
RBS and its 'culture of fear' even after the bank's collapse (see also Martin 2013, whose interviewees also preferred anonymity, and Fraser 2014). We visited the campus on two occasions: on 29 September 2012 and on 15 March 2013 (we were unable to get permission for further visits).

The study also allowed us to reflect on our own experience, as recommended by Bourdieu, who used insights from his Algerian studies to understand and reflect on his own family’s context in the Béarn. We were in a sense 'directed' to this topic by (1) our experiences working for an organization with a dominant leader involved in the construction of a prestigious 'new building' (see Robinson and Kerr 2009), and (2) the relation between Scotland (one of the authors is Scottish), its financial institutions and the financial crisis, which we have studied elsewhere in relation to changes in the leadership of the banks (see Kerr and Robinson 2011, 2012). In the following sections, we begin to unpack the second of these issues.

\section{The corporate campus: circuits of capital conversion}

The new RBS corporate campus was a project initiated by Fred Goodwin who succeeded Sir George Mathewson as CEO in 2000. This succession followed the acquisition by RBS of the much larger London-based NatWest bank, a struggle in which RBS defeated its great historic Scottish competitor, the Bank of Scotland, thus making RBS a major banking power within the UK (Kerr and Robinson 2012; see also Martin 2013; Fraser 2014). This takeover, and the subsequent integration of the RBS and NatWest operations, was widely considered to be a triumph for Goodwin (then Mathewson's deputy), as evidenced by the Harvard Business School case study ‘Masters of Integration’ (Nohria and Weber 2003) and the award of 'Businessman of the year 2002' and the title of 'The world's greatest banker', by Forbes (Morais 2003). Goodwin's prestige was further confirmed in 2004 by a knighthood, conferred by the Queen for 'services to banking' (Martin 2013:161). The success of the NatWest takeover and integration would provide a fund of symbolic capital that Goodwin could draw on in consolidating his position both within RBS and in the field of banking leaders (Kerr and Robinson 2011). As Chief Executive Officer, Goodwin also obtained delegated power as a representative of the shareholders. This however is a power that 'transcends each of the individuals 
who delegate him' (Bourdieu 1984:203), allowing Goodwin to wield the economic capital of the business while accruing economic, cultural and social capital for himself through the trappings of office, such as the new building, salary, bonuses, pension contributions, and private jet (for details, see Martin 2013:138). These forms of capital could then be converted into symbolic capital in other fields, including fields of power.

Following the acquisition of NatWest, RBS planned to consolidate and centralise in a bigger headquarters building (Scotsman 2005). As CEO, Mathewson had planned to move from St Andrew's Square, a city centre site the bank had occupied for over 200 years, to the nearby St James House. This proposed new HQ was 'Sir George [Mathewson]'s vision,” according to a director involved in the project (quoted in Fraser 2000). However, on taking over as CEO in 2001, Goodwin cancelled the St James House project. For Goodwin, the proposed site was 'not the right place, not appropriate for a global business', in part because there was 'a supermarket on the ground floor' (Interview b 2013). Consequently, a new 'high-level brief' for a campus HQ was signed off by the RBS board (Interview a 2013).

As incumbent architects on Mathewson's St James House project, the Edinburgh-based firm Michael Laird Architects (MLA) were retained as 'vision' architects, with the 'aspirational brief to design a world class building' that would attract and keep ‘world class’ staff (Interview a 2013). During the search process, Goodwin rejected 15 other potential sites as failing to meet RBS's criteria of 'a high level of containment, privacy, security, seclusion, exclusivity and quality of environment' (Outline Planning Brief, Sept 2002:33-35). The $16^{\text {th }}$ site identified was Gogarburn, a site of 100 acres in West Edinburgh, $10 \mathrm{kms}$ from the city centre but close to the airport. According to one of our interviewees, Goodwin, having seen the site, said ‘that’s for us’ (Interview a 2013).

Siting the RBS 'global HQ' in West Edinburgh would constitute symbolic capital for those promoting Edinburgh as a 'global business hub'. In 2003, the Scottish Executive, Scottish Enterprise Edinburgh and Lothian, and the City of Edinburgh Council had formed a 'regional growth coalition' (a widely 
popular phenomenon, an example of the spread of neoliberal ideas of competition: Jessop 2002:187; see also Harvey 2012). For the Scottish Executive ('Scottish Government’ from 2007), developing West Edinburgh would present 'a unique opportunity in Scotland to create an international business location, capable of attracting world class companies and headquarters opportunities' (WEPF 2003:11). Developing West Edinburgh as an 'International Business Gateway’ (WEPF 2003), with international corporate HQs situated near the airport (WEPF 2003), would therefore promote Edinburgh as a "”world-class" competitive city... performing against European and Global benchmarks such as Amsterdam, Barcelona and Boston' (CEC Scenario Planning Report 2004). This meant that, as a 'prestige development', the RBS campus would constitute objectified cultural capital for the Council and its allies, enhancing 'the reputation of the Capital City as a world player' (CEC Strategic Response 2002). In conceptual terms, this spatialisation of corporate power demonstrates the conversion of economic capital into cultural capital and potentially into symbolic capital.

However, the Gogarburn site, which had been an 'asylum' or 'mental hospital' until its closure in 1998, was owned by the Lothian Primary Care NHS (National Health Service) Trust (Gazetteer for Scotland 2009). The Trust had already held an open bidding competition to sell the site for noncommercial use and was in negotiations with the preferred bidder, Queen Margaret University College (QMUC), which had recently acquired university status and intended to build a new campus on the site (THES 2001). However, RBS offered the NHS trust a much higher sum for the site (reported as $£ 50$ million by Bain and Robertson 2001). According to the Times Higher Education Supplement, the Principal of QMUC wrote to both Goodwin and Edinburgh Council, 'urging that the organizations work together so both organizations could be accommodated on the site' (THES 2001). However, this offer was rejected by Edinburgh City Council, whose leader Donald Anderson 'made it clear he wanted to see nothing stand in the way of the RBS being able to move to Gogarburn' (as reported in Bain and Robertson 2001). The rejection was also supported by the Lord Provost of Edinburgh, Eric Milligan (Fraser 2014:516). 
However, the City Council's planning brief, drawn up in 1998, stated that the Gogarburn hospital 'brownfield' site should return to 'Green Belt compatible uses' or else be sold for 'institutional (not commercial) use' (Planning Brief 1998:18). In order to change this status (which would have denied RBS use of the site), the bank formulated a 'Global Headquarters Economic Position Statement' (2001) addressed to the City Council. This stated that 'The RBOS headquarters are in Edinburgh because this is historically where their business started and expanded. However, it is now a major international company operating globally'. RBS then pointed out the 'impact of potential loss' on Edinburgh if RBS were to move its HQ to, e.g., London: 'losing RBS would have a severe impact upon the Capital City', it would not only 'affect the reputation of the Capital City as a world player in the financial arena' but could mean that 'as many as 14,000 jobs could be lost in total' (RBS Position Statement, 2002).

In its response to this, the City Council agreed that there would be 'prestige [in] retaining and expanding the HQ of such a large global firm in Edinburgh'; that RBS was 'a cornerstone of the city's economy'; and that the building would be 'a prestige development', with 'major strategic economic advantages to the city and nationally’ (CEC Combined Strategic Construction Response, June 2002). The Council therefore recommended the project go ahead as 'an exceptional circumstance [that] outweighs the current statutory development plan’ (Outline Planning Brief, Sept 2002:36). However, because the decision involved 'a significant departure from the approved Structure Plan', agreement had to be, and was, obtained from the Scottish Ministers (CEC Combined Strategic Construction Response, June 2002:2; RBS Annual report 2002).

This episode shows how the physical space of Gogarburn had become a stake in symbolic competition even before the old hospital was demolished: the imagined new building, which existed as a 'vision', already constituted symbolic capital in the local fields of power. In the 'struggle for the appropriation of space' (Bourdieu 1993), the power of the economic capital of a dominant institution in the financial field was used to mobilise alliances in the field of power - council members, council bureaucrats, government ministers - to overcome the competing claims of QMUC and issues of planning, thus 
demonstrating the comparative power of the field of banking and finance in Scotland vis-à-vis the dominated field of education (in addition, QMUC as a 'new' university having been given that title in 1999, was lacking in the forms of capital possessed the older established Edinburgh HE institutions). This episode also demonstrates how, in the UK in this period, the public interest - and public space was increasingly being colonised by private interests wielding the power of economic capital (Harvey 2012; see also Bourdieu 2000). The RBS corporate campus would turn that economic capital into objectified form.

\section{The corporate campus: capital objectified}

RBS's plan was to build a corporate campus headquarters, a new building that would constitute symbolic capital for the bank. It would also set up a dialectic of distinction between the corporate client and the architects, a relationship that can be seen in the origins and development of the building type. The corporate campus is an architectural typology that originates in post-WW2 USA, the apogee of managerial paternalistic capitalism (Albrecht 2006). The key architects in developing corporate campuses were Gordon Bunshaft of Skidmore Owings and Merrill (SOM), Eero Saarinen (Saarinen and Associates), and Kevin Roche (KRJDA). Bunshaft was designer of campuses for Connecticut General (1957) and Boots in the UK (1967), while Saarinen designed a campus for John Deere (1964) and campus-style 'tech centres’ for General Motors (1956) and IBM (1956). Roche, after designing campuses for Richardson Vicks (1975), Union Carbide (1982) and General Foods (1983), was commissioned to design two campuses in Europe, the 'Challenger' for Bouygues Construction near Paris ('le petit Versailles': Barjot 1992), and Ciudad Financiera Santander near Madrid for Banco Santander (Pelkonen 2011). In addition, a 'village street' variant of the typology was developed by Neils Thorp for the SAS HQ near Copenhagen, and used by Thorp in his design for the BA Waterside campus near Heathrow airport (opened in 1995). In developing these projects, the architects were able to accumulate cultural capital within their own field, while commissioning prestigious architects allowed corporate leaders to accumulate cultural capital in relation to their corporate peers. 
For corporate leaders a campus building serves two further aims (see interview with Roche in Dal Co 1984): to promote the firm as a 'family', or 'community', a task in which the city-centre corporate tower-block offices were deemed to have failed; and to project a corporate identity, on a spectrum running from the discrete and concealed, as with Union Carbide at Danbury, to the ostentatious and highly visible, as with General Foods' baroque palace at Rye Brook (see Pelkonen 2011). For Gogarburn, MLA and RBS decided on a design based on the Neils Thorp sub-type: the campus would feature business 'houses' and an enclosed central street that would be 'dynamic', a place for meeting with cafes and shopping, 'as active a possible' (Interview a 2013).

At the outset, RBS's own in-house team managed the project. Goodwin was however worried about budget control: ‘aspiration and budget didn’t match’ so ‘Fred did his nut’ (Interview b 2013). MACE, a London-based firm of project managers was then brought in, and in turn brought in another firm of architects, RHWL, as MLA was deemed not big enough to handle the project themselves (MLA and RHWL formed a joint venture for this purpose). A 25-26 member project team was formed, colocated on site in a temporary three-story building and including representatives of MLA, MACE, RHWL and RBS . Although MLA was 'always in control', the project was 'Fred's baby', he was 'very hands on’ (Interview b 2013); indeed, reports published after Goodwin had left RBS claim that he was 'obsessed by the building', taking an interest in minute details, to the extent of 'selecting the wallpaper and the thick pile carpets' (Treanor 2012), while according to Fraser, the architects were 'astonished at how hands-on Goodwin was' and that 'he had to win every argument' (Fraser 2014:157).

As 'vision architects', MLA had been asked to 'produce a building that suggests quality but not extravagance' and 'responds to the RBS brand that manages to combine the idea of Scottish fiscal propriety with its role as a global player' (Urban Realm, 2006). The RBS building is not therefore 'iconic' in the sense of drawing attention to itself (see Sklair 2006): instead, it is intended to project a 'Scottish' restraint and discretion to the outside world. The building itself is partly concealed from Glasgow Road by trees (this is the main road to Edinburgh city centre from the airport) and is situated on land that slopes northward away from the road into the countryside, thus meeting RBS's 
requirement for 'containment, privacy, security, seclusion, exclusivity and quality of environment' (Outline Planning Brief, Sept 2002, p33). However, this discretion did not apply outside the campus: on exiting Edinburgh airport a massive billboard used to greet visitors with the message 'Welcome to Edinburgh, global headquarters of Royal Bank of Scotland group’ (as reported by Hattenstone 2009); while, after leaving the airport, the visitor still drives under the Gogarburn bridge, decorated not with the Edinburgh shield but with the RBS logo (City of Edinburgh Council Planning document 2005), intended to provide ‘a visual statement and gateway to Edinburgh' (SKM Consulting 2010 ${ }^{\mathrm{vi}}$ ). However, in that it was completed on budget (£350m) and ahead of time, the RBS campus compared favourably with the 'similarly gargantuan’ but much-delayed and over budget (final cost £314m) Scottish Parliament building (Construction News 2005). The RBS building therefore served to project an image of the power of the bank itself (its corporate identity) and of the Scottish financial sector to the visitor to Edinburgh and Scotland. However, as noted above, the building was also intended to serve an internal organizational purpose, that of producing the corporation as a community - but what sort of community?

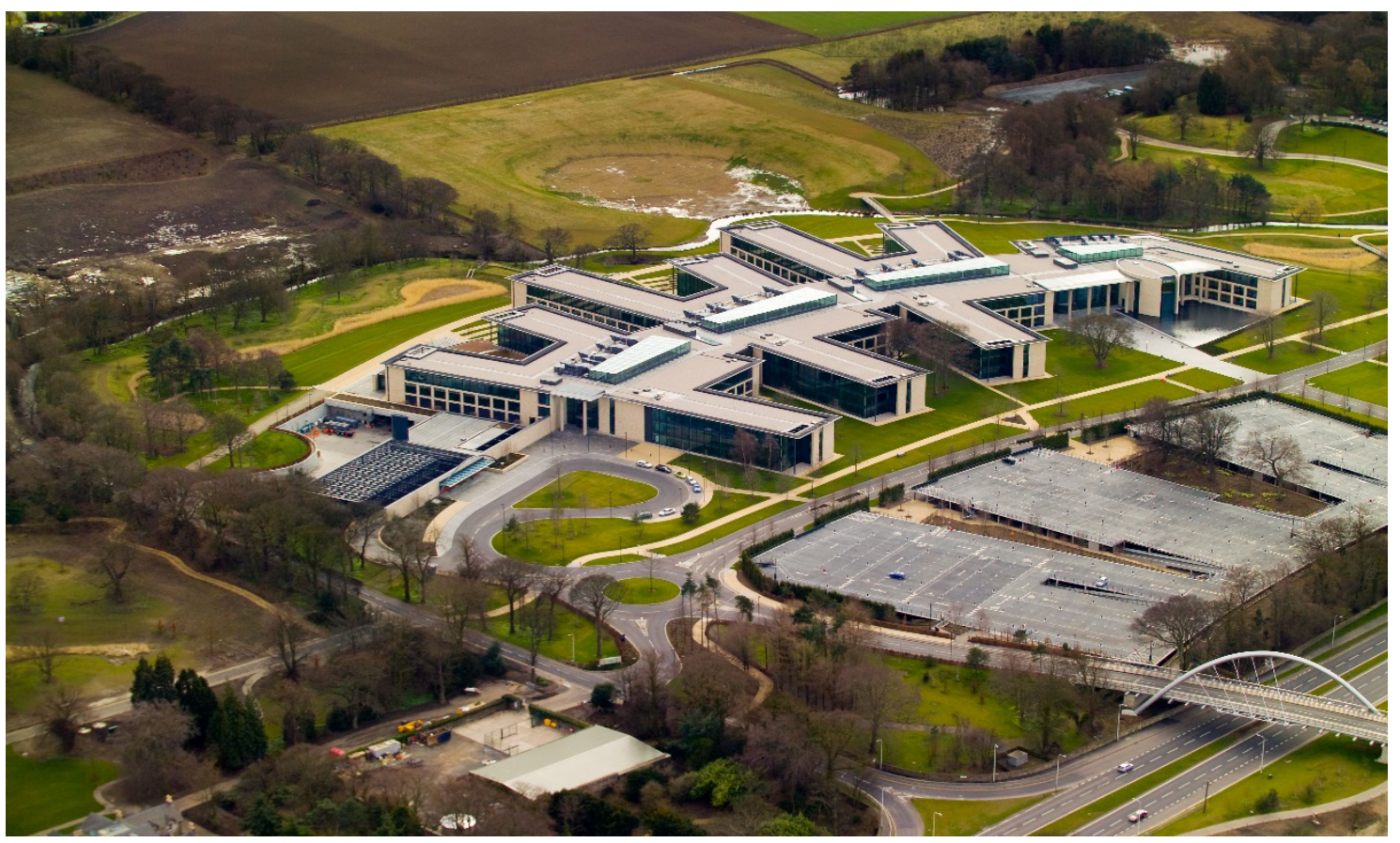


Plate 1 : RBS Gogarburn : the 'street' is flanked by the business houses and leads to the executive house at the far end. The bridge over the main Edinburgh-Glasgow road can be seen on the lower right (C) Alamy.

\section{The corporate campus: hierarchy and physical space}

As designed, the RBS building would in effect reify a symbolic and social hierarchy in physical space: the architects were asked to 'create a village, with an hierarchy: staff in the houses, the executive block as the town hall and a servant class doing the catering, cleaning - the street linked it' (Interview b 2013). The 'village', designed to accommodate 3250 staff, would include a staff restaurant, a Starbucks, a hairdresser, florist, pharmacy, dentist, Tesco supermarket, newsagent and branch bank. A business school and a conference centre, incorporating a 300-seat tiered auditorium and its own television studio were also planned. In addition, the renovated Gogarburn House and its converted stables would contain sports facilities, with a $20 \mathrm{~m}$ pool, jogging tracks, tennis courts, fivea-side football pitches, gym, and medical and fitness suites. There was also a nursery for 70 children (The Gazetteer for Scotland 2010).

Part of the rationale for the design of the campus was to get staff to break out of the 'silos' of RBS's 'very traditional working culture' (Interview a 2013). To this end, staff offices ('workspaces') in the 'houses' which gave off the 'village street', were open plan, and the street itself was broken into 'three distinct sections linked by squares... which give a variety of settings for informal meetings, break-out areas and touchdown spaces’ (Edinburgh Architecture 2012). The street was therefore 'very much part of the working environment' (Clipped News 2005), intended to 'foster "engagement", and the exchange of ideas' and promote 'new ways of working' (RBS Group Communications Director Howard Moody, Scotsman 2005) that would change the incorporated dispositions of the workers (see Duffy 2009 for similar ideas about ‘new ways of working’ in the BA campus ${ }^{\text {vii }}$ ). But open plan offices can also be seen as 'new ways of control' (Hillier and Hanson 1984). According to Howard Moody, 'the whole building is transparent. People can see into it, can see through it, can see people moving about in it' (quoted in Scotsman 2005). However, while the workers would always be visible in the 
open plan offices with the glass-wall windows, or mingling in the street - the corporate elite in the executive offices in the secure Executive House would not be visible in this way ${ }^{\text {viii }}$.

\section{The corporate campus: distinction and cultural dominance}

The Executive House and the boardroom suite constituted a material manifestation and confirmation of the field of power within the corporation, a field of power dominated by Goodwin (Fraser 2014). The Executive House was situated in the 'position of power' (Dovey 1999), approached along the central street (the architectural term is enfilade). As Dovey (1999, drawing on Hiller and Hanson 1984) notes, at Versailles, 'positions of power were located deep within a tree-like or linear structure', while 'the depth of the inhabitant was an indicator of status, and the depth to which visitors were permitted to penetrate also indicated their status' (Dovey 1999:22). This kind of construction of hierarchical distinction, one of the ideological effects of built form, has been continually reproduced throughout history.

So, as at Versailles, and echoed at the Bouygues complex and Ciudad Santander, the office of the King/President/CEO was positioned at the axial point and 'stretched the entire length of one of the building's wings' (Wilson, Aldred and Ahmed 2011). In addition, and again echoing Versailles (Dovey 1999), Goodwin had a private 'stage door' executive entrance, a private lift and a private entrance into the drum-shaped boardroom, positioned as a private chapel would be, next to the kingCEO’s offices (Fraser 2014).

However, the discrete exterior of the building contrasted with the ostentation of the executive house interior. In the board room, the 30ft long 'table of power' (see Jacqueline Hassinck's photo series of boardroom tables, 1996) was produced by a locally-based designer, who also designed the executiveoffice furniture. An 'executive kitchen' was open 24 hours a day. Each of the executives had an individual office in the Executive House, with views over the rolling parkland towards the Pentland Hills. These offices were decorated with salmon pink wood tables and cupboards, and pale blue walls, doors and upholstered chairs ${ }^{\mathrm{ix}}$. Goodwin's office was (according to the Daily Mail, a newspaper 
hostile to Goodwin) 'decorated with wallpaper costing £1,300 a roll' (Malone 2009). There was ‘a fitted gold carpet, a glass trophy commemorating RBS's victory in the bidding battle for NatWest, a bell presented by the mayor of Philadelphia and a painting by Glasgow-born artist Glen Scouller' (heraldscotland 2008). This painting was 'Afternoon Shadows, Collioure' (one of 70 by this artist owned by RBS) in a style of kitsch pseudo-impressionism, a style that borrows the distinction that 'accrued to their (Impressionist) predecessors' in order to 'to claim highbrow socio-cultural distinction’ (Matz 2012: 120-123).

Bourdieu also notes that 'the possession of physical space (vast parks, huge apartments, etc.) [is] a way of keeping at a distance and excluding all sorts of undesirable intrusions' (Bourdieu 1993:257). The campus would constitute a private enclave with security at the door and further security at the executive house (the inner sanctum), thus ensuring Goodwin's privacy and security, while allowing him easy access to his private jet and so 'connected to the global economy', part of the 'international capitalist class' (Sklair 2006), flying to business meetings, international sports events, and other elite gatherings (Martin 2013:151).

But to be part of this transnational field of power, one must already possess the requisite nationallybased forms of capital that can be converted into a more widely recognised form of symbolic capital. And, as in the case of RBS, these forms of capital were dependent on the right to represent the corporation, attained via modes of domination within the corporation itself, both douce, in relation to the seductive aspects of the campus, and harder-edged, in relation to the daily face-to-face morning meetings that Goodwin conducted with senior managers. At these meetings, according to David Appleton (Head of RBS Group Media Relations 1996-2003): 'People were intimidated from speaking their own mind because they feared Fred's reaction and this created an atmosphere around him which inhibited even the most senior people in the bank from expressing their views' (quoted in Bowers and Kochan 2011). 
Given his domination of RBS's internal field of power, Goodwin was able to wield the symbolic power of the bank within Scotland, within the UK and globally (Kerr and Robinson 2012). However, the power of the bank - and its headquarters - were also symbolically valuable for successive Scottish governments after devolution.

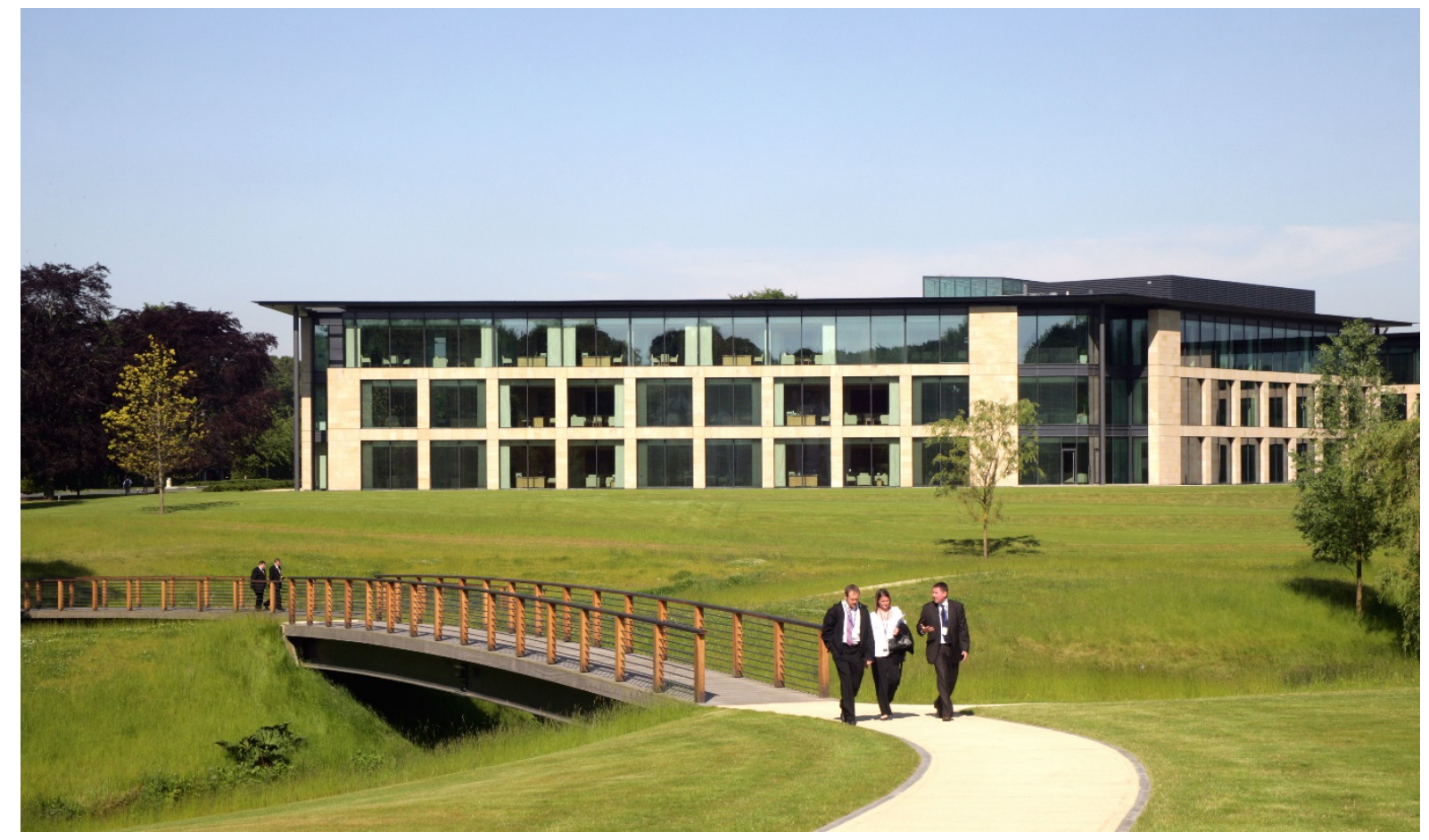

Plate 2: RBS Gogarburn from the south. The executive house with the CEO's office on the top floor looks out over the landscaped park. Photograph (c) Copyright Alamy.

\section{The corporate campus: RBS and the field of power in Scotland}

With Scottish devolved government in 1998, a new field of power was forming in Scotland, constituted by local and national politicians, bureaucrats, business leaders, lawyers and senior academic administrators (Hassan and Shaw 2012). In this context, the 'aspirational' new RBS HQ counted as symbolic capital for Edinburgh City Council, for the Scottish Executive, for RBS, and for Goodwin as its Chief Executive Officer. These inter-relationships also reinforced the symbolic power of the Scottish banks (RBS and the Bank of Scotland) as 'nodal' institutions (along with the Church of Scotland, the legal and educational systems, and the media), in the construction and perpetuation of Scottish national identity (Sewell 1999; Kerr and Robinson 2012). As expressed by Queen Elizabeth 
at the official opening of the Gogarburn campus in 2005, 'this building is a fine tribute to the many generations of "canny" Scottish bankers, who have made - and are still making - such a valuable contribution to the national economy' (quoted on the official website of the British Monarchy 2005).

At a national level, then, RBS and its new building counted as cultural and symbolic capital for Scottish politicians, contributing to a shared and dominant neoliberal imaginary of 'a smart successful Scotland' that would be 'business friendly' (Scottish Executive, 2004; see Davidson, McCafferty and Miller 2010). At the Gogarburn opening ceremony, Jack McConnell, First Minister and Labour MSP, emphasised RBS’s strategic importance for the Scottish government: 'Building world-class Scottish companies... is a central part of our strategy for developing a modern and prosperous Scottish economy. The Royal Bank of Scotland is a perfect realisation of that ambition' (Scottish Government 2005). (Also in attendance, from the political field, were: Alistair Darling as Secretary of State for Scotland, and Lord Provost Lesley Hinds: see Martin 2013, who was present at the ceremony).

Similarly, on becoming Scottish First Minister in 2007, Scottish National Party (SNP) leader Alex Salmond, in the course of a speech at Harvard University, evoked a future independent Scotland that would form part of a North Atlantic 'arc of prosperity', comprising Scotland, Ireland, Iceland and the Nordic countries ('Scotland the Celtic Lion', BBC 2007). According to Salmond, 'with RBS and HBOS (Halifax Bank of Scotland) - two of the world's largest banks - Scotland has global leaders today, tomorrow and for the long-term' (Scottish Executive, First Minister 2007).

This confirms how a powerful bank in a small nation could succeed in aligning its interests with what politicians took to be the interests of the nation itself by converting the power of its economic capital into symbolic capital that can be cashed in the field of power (on the dangers of this, see the Special Investigation Commission of the Icelandic Parliament: SIC 2010) ${ }^{\mathrm{x}}$.

The new Scottish banking elite, of whom Goodwin was a leading example, aspired to accede to fields of power at UK, European and ultimately global levels (Kerr and Robinson 2012). Now, in constructing a new campus HQ, RBS emulated Banco Santander, another regional bank on its way to national and global success, in that Santander had moved to an immense new campus headquarters, 
designed by Kevin Roche, in 2004. In fact, RBS and Santander had a long-standing relationship: Santander's President, Emilio Botìn, had been on the RBS board until 2004, and would be one of RBS's partners in the ABM Amro takeover (see Fraser 2014 on Goodwin's quasi-filial relationship with Botin). In seeking out architects who were part of the dominated sector of the architectural field, rather than the consecrated elite such as Roche, perhaps Goodwin and RBS were unconsciously affirming a subordinate position vis-à-vis Santander? Or was it also that Goodwin wanted to dominate the architects - 'play the architect' ${ }^{\mathrm{xi}}$ - in a way that would have been impossible with, e.g., the renowned Roche? So we can trace the process of circulation by means of which, for Goodwin as social agent, forms of capital (economic primarily) were converted into modes of domination (soft and hard) which could then be reconverted into symbolic capital, cultural primarily, but also social, as evidenced by invitations to attend Grands Prix, where RBS and Santander sponsored competing Formula One teams, invitations to events such as the 'Enchanted Garden Ball' (Reid 2008), or to chair the Prince’s (i.e., Prince Charles’s) Trust and the Queen’s Silver Jubilee Trust.

By 2004, however, Goodwin was beginning to be seen by some investment analysts as a liability, a 'megalomaniac', who constituted a 'management discount' on the RBS share price (see remarks by James Eden from Dresdner, in RBS 2005). With the slow depletion of the symbolic capital that Goodwin had accumulated in the NatWest integration (captured in his nickname 'Fred the shred'), the HQ also began to be seen, for a small minority of 'heretical' employees within the corporation, as a negative symbol of Goodwin's leadership ('Fredinburgh'), and aspects of the business, including the building and its furnishings, were seen by RBS’s credit-risk managers to signal impending insolvency.

According to former RBS employees (interviews e and f), all credit-risk managers are familiar with Bill Mackey’s ‘somewhat tongue-in-cheek’ list of 14 impending insolvency indicators that credit managers look out for when assessing credit risk (Bill Mackey was a very influential and much referred to figure in the risk-assessment field). Of these indicators, up to eight could be identified when the credit managers visited Gogarburn and the London office at Bishopsgate: for Mackey, the presence of five or more would signal irreversible decline (see Bullivant 2004:152). These indicators 
were: (1) company cars with personalized plates (private jet with insignia 'RBSG' for 'RBS Goodwin'); (2) a fish-tank (in Johnny Cameron's executive office in London and the RBS Gogarburn water feature with fountains); (3) flag pole with corporate flag (the bridge over the Glasgow Road with RBS logo); (4) three or more knighted directors (in 2003 Mathewson, Vallance, Robson); (5) Chairman honoured for services to industry (in 2003, Mathewson, then MacKillop); (6) recently moved to super-modern offices (officially opened by a dignitary); (7) audit partner went to school with CEO (Goodwin had been a partner in Deloitte and Touche (D\&T), 1988-95, and appointed D\&T as RBS's auditors when he became CEO of RBS); (8) Chairman well-known for political work (Mathewson was an active SNP supporter; his predecessor, Lord Younger, had been a government minister).

The significance of these signs was, however, confined to a small group of employees, none of whom wished to draw attention to themselves as whistleblowers. For others, according to Hunt, a senior HR manager at Gogarburn, 'we all had implicit faith in the executives, and Fred Goodwin in particular... we utterly believed... failure in any respect was never contemplated' (Hunt 2010: 46-47). For these employees, Goodwin was the embodiment of the corporation and the guarantee of its continuing success.

\section{Discussion}

In our analysis, we have applied Bourdieu's concepts to the planning and development of the RBS corporate campus. We now turn to a discussion of what this analysis might contribute to an understanding of symbolically powerful buildings and elite field of power mobilisations. In discussing symbolically powerful buildings, Bourdieu (1967), Pinto (1991), and Williams (1977) show how projecting social power/domination through architecture involves an inescapable interaction in the design process between architects and patrons (e.g., the Church, the aristocratic estate owners); and although contemporary architects, both 'artists' and 'mass producers', are seen as servants of 
capitalist corporations (Harvey 1990), they still operate within a dialectic of distinction in which there is mutual reinforcement of position between architect and client (Lipstadt 2003).

However, in our study of the RBS building, we are able to identify a more complex interplay of field positions and circuits of capital. Of course, interactions between RBS and the architectural field certainly create a dialectic of distinction (MLA's website would indicate this), but there is also a mutual reinforcement of distinction between the political and financial fields through a complicity of material and symbolic interests at both local and national levels. In other words, there is an interconnection between corporate power and state power which is at the same time a demonstration of RBS's 'power over the power of the state' and an assertion of the dominance of the financial (primarily) and the political fields vis-à-vis education and the bureaucratic field. This understanding of how the RBS building counted as a stake in different fields underlines the benefit of using Bourdieu's concepts, not just as an interconnected framework (see Golsorkhi et al. 2009), but as a dynamically interacting system that can capture the dynamism of these interacting fields, including the field of power, showing that are not in static equilibria, but constantly in motion.

The same dynamic interaction is true of the circuits of capital conversion by means of which Goodwin, through his office and in his person, was able to accrue different forms of capital (incorporated, reified, social). Of course, in order to do this, Goodwin had first to be able to wield the economic capital of the firm (i.e. not his own economic capital), and in order to do this he had to ensure his continued domination within the organization's field of power. This domination required a constant effort of reinforcement, a labour of reaffirmation through day-to-day practices of symbolic violence, on a continuum of douce - providing restaurants, swimming pools, etc. - to hard modes of domination - e.g., face-to-face meetings (Kerr and Robinson 2012).

In addition, the building's design and layout physically affirmed Goodwin's position within the corporate power structure through his capture of the office of chief executive and his domination of the executive team and the board (see Fraser 2014). The 'new building' thus reproduced his power through 'the symbolic violence of constructed space' (Wacquant, 2002:33) produced in part by 
Goodwin's micro-management of its construction. It also served to perpetuate Goodwin's legacy (Robinson and Kerr 2009), in that the building was associated with Goodwin via informal associations and through beliefs about his particular interest in the building's design and furnishings (see, e.g., Treanor 2012; Fraser 2014).

We might go on to argue that, while RBS as a corporation was able to leverage the restrained, discrete public image of a well-run traditional bank as projected by the headquarters, internally, Goodwin and the other executives backed by the board (see Scottish Parliament EETC 2009: col2727) were taking decisions based on a high-risk growth-through-acquisition strategy that culminated in the ABN Amro takeover that would prove disastrous for the bank and contribute to the British economic crisis in $2009^{\text {xii }}$. With the imminent collapse of the bank the 'implicit belief' in Goodwin's power ended: it was a condition of the UK government's bail-out that Goodwin should resign (Martin 2013). The reputation of the banking and finance sector in the UK was also devalued following the crash in which not only RBS but also Northern Rock and HBOS (Halifax Bank of Scotland) had to be rescued by the government.

After the near death of RBS , what had been 'Fredinburgh' (Interview c), the 'utopian head office' (Bain and Robertson 2005), 'a private building, reminiscent of those Elysian days of the later 19th century in which projects were commissioned by rich and mighty clients who wanted to fashion the world in their image' (Urban Realm 2006), with Goodwin as 'the roi soleil of Gogarburn’ (Mount 2010), became instead a symbol of Goodwin's ambition and failure: ‘Goodwin Towers 'xiii, ‘Fred’s Folly', and a ‘cathedral of hubris’ (Armitstead 2009).

This confirms Dovey's (1999) contention that a building does not in and of itself constitute a lasting form of reified capital: it can be devalued or revalued according to the changing context. So, following Goodwin's fall, the building and its meaning became a further stake in the struggles to make sense of, or impose sense on, the financial crisis. For sections of the media, the building was symbolic of the 'greed' of the bankers that ended in the crash (according to Slater 2012, RBS cut 
34,000 jobs worldwide between 2009 and 2012, 22,000 of those being in the UK). A period of repentance was required, with changes to the company and the building introduced to show that the 'age of excess' was over. New management was brought in by the UK government, and, according to Armitstead, who visited the campus soon after the collapse in 2009: 'Sir Fred's opulent executive wing... lies almost empty. Managers now share the open plan floors with their staff' (Armitstead 2009). Mathieson, who also visited the campus to meet new CEO Stephen Hester, noted that, 'Hester is leading by example. He will now be sharing an office... The executive wing's huge offices are being replaced by an open-plan space for around 400 workers' (Mathieson 2009). This means that the building had a continuing symbolic role, but now designed to show that the executives would no longer spatially distinguish themselves from their employees: no longer be disconnected from the organization, but 'one of us'. This symbolic posture appears to revert to what Bourdieu would term a 'softer' mode of domination, a form of symbolic violence apparently more attuned to the post-crisis humility required of bankers, as recommended by for example the UK Parliamentary Commission on Banking Standards (2013).

\section{Conclusions}

In the introduction to this paper we set out to address the following questions. What is the relationship between corporate space and the field of power? What role does a corporate building play in circuits of capital conversion? And what does this case tell us about the role of architecture in elite mobilisations?

In addressing these questions, we argued that, in the period before 2009, the RBS campus counted as symbolic capital (Bourdieu 1993), not only for CEO Sir Fred Goodwin, but also for RBS as an organization, for Edinburgh as a city and for the Scottish government. We identified how the economic power of the bank - as delegated to Goodwin, its officer - was converted into objectified cultural capital that counted as symbolic capital in different fields and in turn reproduced symbolic power. We also showed how the building counted as a stake in different fields, while, as social space, it reproduced asymmetrical power relations through modes of domination: first, by a direct, 
interpersonal domination but also by a more diffuse, mediated, yet omnipresent seductive mode. Internally, the discrete exterior was contradicted by the ostentation of the executive house; and while the corporate 'family' was kept close and secure, the outside was kept at a distance.

Finally, we suggested that, after the collapse of RBS in 2009 and Goodwin's resignation as CEO, the campus counted as what we might term (by analogy with Wacquant 1998) negative symbolic capital for the bank's leadership, showing how the meaning-potential of the building changed - reflecting changes in the socio-economic context. However, the campus now (2015) has an ambiguous status vis-à-vis Scotland; counting as negative capital in retrospect to RBS in the Goodwin era, yet its physical and symbolic presence in Scotland was evoked in the independence referendum debates in the autumn of 2014, with the threat by RBS to relocate its headquarters to London in the event of a 'Yes' vote for independence amounting to renewed symbolic capital in the political field for the proponents of the 'No' vote (Scuffham 2014). The independence referendum debate also drew attention to the potential danger for an independent Scotland in hosting 'too big to fail' banks: in 2009 it was the UK state that bailed out the Scottish banks, while in Iceland the government allowed the banks to collapse (see SIC 2010).

In conclusion, we argue that our analysis of corporate architecture has broader significance for critical organizational scholarship in terms of understanding the role of corporate buildings in circuits of capital and in particular the role of buildings in elite mobilisations, i.e., how different fields and elite social agents in those fields interact to mobilise material and symbolic resources. In providing insights into elite power relations, the innovative approach that we develop extends the scope of Bourdieusian field theory in organization studies to include inter-field dynamics and field of power interactions. Further research could well extend this approach either within the banking field (e.g., the Santander $\mathrm{HQ}$ ), or to more recent high-profile headquarters projects, such as the 'shining ring' headquarters planned by Apple (designed by Sir Norman Foster), Google’s ‘futuristic greenhouse’ (designed by Thomas Heatherwick), and Facebook’s ‘Facebook West’ (designed by Frank Gehry). 


\section{References}

Albrecht, D. (2006) The clients and their architect. In Pelkonen, E-L. and Albrecht, D. (Eds). Eero Saarinen: shaping the future. New Haven and London: Yale University Press.

Armitstead, L. (2009) Open plan bosses leave Gogarburn grandeur behind. The Telegraph, 15 Dec 2009, athttp://www.telegraph.co.uk/finance/comment/6820047/Open-plan-bosses-leave-Gogarburngrandeur-behind.html

Bain, S. and Robertson, L. (2001) Royal Bank closes in on Gogarburn site deal. The Herald, 4 May 2001, at http://www.heraldscotland.com/sport/spl/aberdeen/royal-bank-closes-in-on-gogarburn-site$\underline{\text { deal-1.188982 }}$

Barjot, D. (1992) Francis Bouygues. L'ascension d'un entrepreneur (1952-1989). Vingtième Siècle. Revue d'histoire, 35: 42-59.

BBC (2007) Salmond gives Celtic Lion vision, at http://news.bbc.co.uk/1/hi/scotland/7042726.stm

Beaud, S. and Pialoux, M. (1999) Retour sur la condition ouvrière. Enquête aux usines Peugeot de Sochaux-Montbéliard. Paris: Fayard.

Biau, V. (1998). Stratégies de positionnement et trajectoires d'architectes. Sociétés Contemporaines, 29: 7-25.

Bourdieu, P. (1962). Célibat et condition paysanne. Études rurales, №5-6 : 32-135.

Bourdieu, P. (1967) Postface to E. Panofsky, Architecture gothique et pensée scholastique. Paris : Les éditions de minuit.

Bourdieu, P. (1972) Esquisse d'une théorie de la pratique, précédé de trois études d'éthnologie kabyle. Geneva: Droz. 
Bourdieu, P. (1976) Les modes de domination. Actes de la recherche en sciences sociales. Vol. 2, n²-3, La production de l’idéologie dominante,122-132.

Bourdieu, P. (1977) Outline of a theory of practice. Cambridge: Cambridge University Press.

Bourdieu, P. (1980) Le sens pratique. Paris: Les éditions de minuit.

Bourdieu, P. (1984) La délégation et le fétichisme politique. Actes de la recherche en sciences sociales. Vol. 52-53, Le travail politique. pp. 49-55.

Bourdieu, P. (1985) Social Space and the Genesis of Groups. Theory and Society, 14/6: 723-744.

Bourdieu, P. (1986) The forms of capital. In J.G. Richardson (Ed.), Handbook of theory and research for the sociology of education. New York: Greenwood Press (pp. 241-258).

Bourdieu, P. (1990) Droit et passe-droit [Le champ des pouvoirs territoriaux et la mise en oeuvre des règlements] Actes de la recherche en sciences sociales, 81; 86-96.

Bourdieu, P. (1991a) Social space and symbolic space: Introduction to a Japanese reading of distinction. Poetics Today, 12/4: 627-638.

Bourdieu, P. (1991b) Language and symbolic power. Cambridge: Polity.

Bourdieu, P. (1992) Les règles de l'art : genèse et structure du champ littéraire. Paris: Seuil.

Bourdieu, P. (1993) (Ed.) La misère du monde. Paris: Editions du Seuil.

Bourdieu, P. (1994) Rethinking the state: genesis of structure of the bureaucratic field. Sociological Theory, 12/1: 1-18. 
Bourdieu, P. (1998) Practical reason: On the theory of action. Cambridge: Polity.

Bourdieu, P. (2000) Les structures sociales de l'économie. Paris: Éditions de Seuil.

Bourdieu, P. (2002) Le Bal des célibataries. Points Essais No 477.

Bourdieu, P. (2012) Sur l'état. Paris: Raisons d'agir/Seuil.

Bourdieu, P. and Wacquant, L. J. D. (1992) An invitation to reflexive sociology. Cambridge: Polity Press.

Bowers, S. and Kochan, N. (2011) Former RBS investment banking boss heads off FSA criticism of role in crisis, The Observer, 11 Dec 2011, http://www.theguardian.com/business/2011/dec/11/rbsbanking-boss-crisis-fsa

Bowman, A., Froud, J., Johal, S., Moran, M. and Williams, K. (2013) Business elites and undemocracy in Great Britain: a work in progress. CRESC Working Paper Series, Working Paper No.125.

Bullivant, G. (2004) Assessing credit risk. In B. Edwards (ed) Credit management handbook $5^{\text {th }}$ Edition. Aldershot: Gower, 79-146.

Bunshaft, G. 1990. Oral history of Gordon Bunshaft. Interviewed by B.J. Blum. Chicago: The Art Institute of Chicago.

Carter, C. and Spence, C. (2014) Being a Successful Professional: An Exploration of Who Makes Partner in the Big 4. Contemporary Accounting Research, 31/4: 949-981.

Chamboredon, J-C. 1977. Introduction to R. Williams, 'Plaisantes perspectives, Invention du paysage et abolition du paysan'. Actes de la recherche en sciences sociales, 17-18: 450-452.

Clipped News (2005) Gogarburn the way to go? at 
http://clippednews.blogspot.co.uk/2005/09/gogarburn-way-to-go.html

Construction News (2005) Royal Bank of Scotland HQ, Gogarburn: the project of the decade, 1

December, 2005 http://www.cnplus.co.uk/news/royal-bank-of-scotland-hq-gogarburn/387687.article

Dal Co, F. (1985) Kevin Roche. New York: Rizzoli.

Davidson, N., McCafferty, P. and Miller, D. (2010) (Eds.) Neo-liberal Scotland: Class and society in a stateless nation. Cambridge: Cambridge Scholars Publishing.

Delsaut, Y. (1992) La Place du maître. Une chronique des écoles normales d'instituteurs. Paris: L'Harmattan.

Dovey, K. (1999) Framing places. Mediating power in built form. London, Routledge.

DTZ (2008) West Edinburgh: International business gateway market assessment. Edinburgh: DTZ.

Duffy, F. (2000) New ways of working - a vision for the future. In Clements-Croome, D. (Ed) Creating the Productive Workplace, London: E. and F.N. Spon.

Edinburgh Architecture (2012) at http://www.edinburgharchitecture.co.uk/rbs_lighting.htm

Emirbayer, M., and Johnson, V. (2008) Bourdieu and organizational sociology. Theory and Society, 37: $1-44$

Fessy, W. and McIntosh, S. (2008) (Eds.) The New Scottish Enlightenment. Southend-on-Sea: The Times Group.

Fowler, B. and Wilson, F. (2004) Women architects and their discontents, Sociology, 38/1: 101-119.

Fraser, I. (2000) Fred’s new Fawlty Towers. Sunday Herald, 15 Oct 2000, at http://www.ianfraser.org/freds-new-fawlty-towers/ 
Fraser, I. (2014) Shredded. Inside RBS, the bank that broke Britain. Edinburgh: Birlinn Limited.

FSA (2011) The failure of the Royal Bank of Scotland. London: The Financial Services Authority.

Gazetteer for Scotland (2009) http://www.scottish-places.info/features/featurefirst16944.html

Golsorkhi, D., Leca, B., Lounsbury, M. \& Ramirez, C. (2009). Analysing, accounting for and unmasking domination: On our role as scholars of practice, practitioners of social science and public intellectuals. Organization 16/6: 779-797.

Harvey, D. (1990) The condition of postmodernity. London: Blackwell.

Harvey, D. (2012) Rebel Cities: From the right to the city to the urban revolution. London, New York: Verso.

Harvey, C., \& Maclean, M. (2008) Capital theory and the dynamics of elite business networks in Britain and France. Sociological Review, 56: 105-120.

Hassan, G. and Shaw, E. (2012) The strange death of Labour Scotland. Edinburgh: Edinburgh University Press.

Hassink, J. (1996) The table of power, Amsterdam: Menno van de Koppel.

Hattenstone, S. (2009) Sir Fred, just say sorry. The Guardian, 24 Jan 2009, at http://www.guardian.co.uk/business/2009/jan/24/fred-goodwin-rbs

heraldscotland (2008) A gleaming legacy, The Herald, 14 October 2008

http://www.heraldscotland.com/a-gleaming-legacy-from-era-when-firm-was-among-biggest-in-world1.891983. 
Hillier, B. and Hanson, J. (1984) The social logic of space. Cambridge: Cambridge University Press.

Jessop, B. (2002) The future of the capitalist state. Cambridge: Polity Press.

Jones, P. (2009) Putting architecture in its social place: A cultural political economy of architecture, Urban Studies, 46: 2519.

Jones, P. (2011) The sociology of architecture. Liverpool: Liverpool University Press.

Kamoche, K., Kannan, S. and Siebers, L.Q. (2014) Knowledge-sharing, control, compliance and symbolic violence. Organization Studies 35/7: 989-1012.

Kerr, R., \& Robinson, S. (2009). The hysteresis effect as creative adaptation of the habitus: Dissent and transition to the 'corporate' in post-Soviet Ukraine. Organization, 16: 829-853.

Kerr, R. and Robinson, S. (2011) Leadership as an elite field: the role of the Scottish banks in the crisis of 2007-2009, Leadership, 7/2: 151-173.

Kerr, R. and Robinson, S (2012) From symbolic violence to economic violence: The globalizing of the Scottish banking elite. Organization Studies, 33: 247-266.

Leander, A. (2008) The 'realpolitik of reason'. In A. Klotz and D. Prakash (Eds.), Qualitative methods in international relations. Basingstoke, UK: Palgrave Macmillan, 11-27.

Lipstadt, H. (2003) Can 'art professions' be Bourdieuean fields of cultural production? The case of the architecture competition, Cultural Studies, 30(3/4): 390-419.

Maclean, M., Harvey, C., \& Chia, R. (2010). Dominant corporate agents and the power elite in France and Britain. Organization Studies, 31: 327-348.

Maclean, M., Harvey, C. and Kling, G. (2014) Pathways to power: class, hyper-agency and the French corporate elite. Organization Studies, 35(6): 825-855. 
Malone, A. (2009) Oh no, look who's back! Daily Mail, 14 Nov 2009, at

http://www.dailymail.co.uk/news/article-1227690/Oh-look-whos-Fred-The-Shred-Goodwin-returnshome-determined-rebuild-fortune.html\#ixzz2bBJP2Qrz

Martin, I. (2013) Making it happen: Fred Goodwin, RBS and the Men Who Blew Up the British Economy. London: Simon \& Schuster.

Mathieson, J. 2009. Royal Bank of Scotland directors lose their subsidised sandwiches. Daily Record, 21 April, http://www.dailyrecord.co.uk/news/scottish-news/royal-bank-scotland-directors-lose$\underline{1019402}$

Matz, J. 2012. Pseudo-Impressionism? In D. James (Ed.) The legacies of modernism: Historicising postwar and contemporary fiction. Cambridge: CUP, 114-132.

Montlibert, C. de (1995) L'impossible autonomie de l'architecte: sociologie de la production architecturale. Strasburg: Presses universitaires de Strasbourg.

Morais, R.C. (2003) Brisk and brusque. Forbes, http://www.forbes.com/global/2003/0106/034.html

Mount, F. (2010) The new few: or, a very British oligarchy. London: Simon and Schuster.

Nohria, N. and Weber, J. (2003) Royal Bank of Scotland: Masters of integration. Cambridge, MASS: Harvard Business School.

Official website of the British Monarchy (2005) The Queen opens bank complex, at https://www.royal.gov.uk/LatestNewsandDiary/Speechesandarticles/2005/TheQueenopensanewbankc omplexinEdinburgh.aspx

Parliamentary Commission on Banking Standards (2012-2013) Report. London: Stationery Office. 
Pelkonen, E-L. (2011) (Ed.) Kevin Roche: architecture as environment. New Haven and London: Yale University Press.

Pelkonen, E-L. and Albrecht, D. (2006) (Eds) Eero Saarinen: shaping the future. New Haven and London: Yale University Press.

Pinçon, M. and Pinçon-Charlot, M. (2001) Dans les beaux quartiers. Paris: Seuil.

Pinçon, M. and Pinçon-Charlot, M. (2005) Voyage en grande bourgeoisie. Journal d'enquête. Paris, Presses Universitaires de France.

Pinçon, M. and Pinçon-Charlot, M. (2007). Les ghettos de Gotha : au cœur de la grande bourgeoisie. Paris: Seuil.

Pinto, L. (1991) Déconstruire Beaubourg: art, politique et architecture. Genèses, 6: 98-124.

Reid, S. (2008) Harburn House plays host to JK Rowling. Estate-life, 1 Sept 2008, http://www.estatelife.com/news/2008/09/harburn-house-plays-host-to-jk-rowling

Robinson, S., \& Kerr, R. (2009). The symbolic violence of leadership: A critical hermeneutic study of leadership and succession in a British international organization in the post-Soviet context. Human Relations, 62: 877-905.

Savage, M., \& Williams, K. (2008). Elites remembered in capitalism and forgotten by social sciences. Sociological Review, 56 : 1-24.

Sayad, A. (1995) Un Nanterre algérien, terre de bidonvilles. Paris: Éditions Autrement.

Scotsman (2005) Sir Fred's crowning glory, 9 Jan 2005, at http://www.scotsman.com/business/banking/sir-fred-s-crowning-glory-1-1401384 
Scotsman (2009) Artworks from the Royal Bank of Scotland's collection are to go on show to the public, at http://www.scotsman.com/news/artworks-from-the-royal-bank-of-scotland-s-collection-areto-go-on-show-to-the-public-1-771541

Scottish Affairs Committee (2009) Second Report: banking in Scotland. London: The Stationery Office Ltd.

Scottish Executive (2004) A smart, successful Scotland: Strategic direction to the enterprise network and an enterprise strategy for Scotland. Edinburgh: The Scottish Executive.

Scottish Executive, CEC, Scottish Enterprise (2003) West Edinburgh Planning Framework (WEPF). Edinburgh: Scottish Executive.

Scottish Government (2005) New RBS headquarters press release, at http://www.scotland.gov.uk/News/Releases/2005/09/14110145

Scottish Government (2008) West Edinburgh Planning Framework (WEPF). Edinburgh: Scottish Government.

Scottish Parliament Economy, Energy and Tourism Committee (2009) Financial Services Enquiry, Official Reports on http://archive.scottish.parliament.uk/s3/committees/eet/2009.htm

Scuffham, M. (2014) RBS, Lloyds to move south if Scots vote for independence, Reuters, 11 Sept 2014, http://uk.reuters.com/article/2014/09/11/uk-scotland-independence-rbsidUKKBN0H60ER20140911

Sélimanovski, C. (2009) Effets de lieu et processus de disqualification sociale. Espace populations sociétés, 2009/1.

SIC (2010) Report of the Special Investigation Commission of the Icelandic Parliament, at http://www.rna.is/eldri-nefndir/addragandi-og-orsakir-falls-islensku-bankanna-2008/skyrslanefndarinnar/english/ 
Sewell, W. H. (1999). The concept(s) of culture. In V.E. Bonnell and L. Hunt (Eds), Beyond the Cultural Turn: New Directions in the Study of Society and Culture. Berkeley, CA: University of California Press, 55-61.

Sklair, L. (2006) Iconic architecture and capitalist globalization, City, 10:01: 21-47.

Slater, S. (2012) RBS to cut 4,450 jobs in fresh jobs cull, Reuters, at http://in.reuters.com/article/2012/01/12/rbs-idINDEE80B07C20120112

Stevens, G. (1998) The favored circle: The social foundations of architectural distinction. London: MIT Press.

Swartz, D. (1997) Culture and power: the sociology of Pierre Bourdieu, Chicago: U of Chicago Press.

Swartz, D. L. (2008) Bringing Bourdieu's master concepts into organizational analysis. Theory and Society, 37: 45-52.

Swartz, D.L. (2013) Symbolic power, politics and intellectuals: the political sociology of Pierre Bourdieu. Chicago and London: University of Chicago Press.

THES: Times Higher Education Supplement (2001) QMUC fights for Edinburgh campus site, THES, 20 Apr 2001, at http://www.timeshighereducation.co.uk/news/qmuc-fights-for-edinburgh-campussite/159249.article.

Treanor, J. (2012) Sir Fred Goodwin: The life and times of a modern capitalist, The Guardian 19 Jan 2012, at http://www.theguardian.com/business/2012/jan/19/sir-fred-goodwin-life-times-rbs.

Treasury Committee (2012) The FSA's report into the failure of RBS. London: The Stationery Office Limited. 
Urban Realm (2006) Public but private. Urban Realm, 26 Jan 2006, at

www.urbanrealm.com/features/36/Public_but_private.html

Vaara, E. and Faÿ, E. (2012) Reproduction and change on the global scale: a Bourdieusian perspective on management education. Journal of Management Studies 49/6: 1023-1051.

Violeau, J.-L. (1999) Mai 68-Mai 81: l'entre-deux-Mai des architectes, intineraires intellectuals.

Paris: In Extenso.

Wacquant, L.J.D. (1998) Negative social capital: state breakdown and social destitution in America’s urban core. Netherlands Journal of Housing and the Built Environment, 13/1:25-40.

Wacquant, L.J.D. (2002) De l’idéologie à la violence symbolique: Culture, classe et conscience chez Marx et Bourdieu. In J. Lojkine (Ed.), Les sociologies critiques du capitalisme. Paris: Presses Universitaires de France, 25-40.

Wacquant L. (2005a) Les deux visages du ghetto. Actes de la recherche en sciences sociales, 160.

Wacquant, L.J.D. (2005b) Symbolic power in the rule of the "state nobility". In Pierre Bourdieu and democratic politics. L. Wacquant (ed.). Cambridge: Polity, 133-150.

Wacquant L. (2006) Parias urbains. Paris: La Découverte.

Williams, R. (1977). Plaisantes perspectives, Invention du paysage et abolition du paysan. Actes de la recherche en sciences sociales, 17-18: 450-452.

Williams, G. and Filippakou, O. (2009). Higher education and UK elite formation in the twentieth century. Higher Education, 59: 1-20.

Zald, M. N., \& Lounsbury, M. (2010) The Wizards of Oz: Towards an institutional approach to elites, expertise and command posts. Organization Studies, 31: 963-996. 
${ }^{\mathrm{i}}$ This is one of three ethnological studies published in the French edition of Esquisse d'un théorie de la pratique (Bourdieu 1972), and as an annexe to Bourdieu (1980). The study is included in the English version of Le Sens pratique, translated as The logic of practice (Bourdieu 1990, pp271-283).

ii Michel Pinçon talks about attending Bourdieu’s lectures at Lille University in Loïc Wacquant et Michel Pinçon, à propos de Pierre Bourdieu, 2012 :

http://pierrebourdieuunhommage.blogspot.co.uk/2012/01/ecouter-loic-wacquant-et-michelpincon.html

iii Les modes de domination first appeared in 1976 in Actes de la recherche en sciences sociales. It then appeared in English translation in 1977 in 'Outline of a theory of practice', which is the English translation of Esquisse d'une theorie de la pratique, although 'Les modes' does not appear in the French original. Its first appearance in book form in French was in Le sens pratique (1980), translated as ‘The Logic of Practice’ (1990: 122-134)

${ }^{\text {iv }}$ Bourdieu uses douce in relation to symbolic violence. This is translated into English as 'soft', but the French term has also the connotation of 'sweet' or even 'discreet' (according to Le Petit Robert). ` This three-storey project office must be the origin of the Times' claim about Goodwin's on-site 'cabin', to which Goodwin to such exception that he took the newspaper to court (see Martin 2013). ${ }^{\text {vi }}$ Sinclair Knight Merz, who designed and built the RBS bridge, was acquired by Jacobs in 2013: there are no longer references to the RBS bridge on the Jacobs website (as of August 2014). The reference we give is to a screen-shot of the SKM website captured by us in 2013.

${ }^{\text {vii }}$ For an idealised picture of life on the campus, produced by RBS public relations, see http://vimeo.com/11622435

viii This distinction between individual executive offices and 'visible' open plan offices was already a feature of the corporate campus as designed by Bunshaft for Connecticut General Insurance in the 1950s (Bunshaft 1990).

${ }^{\text {ix }}$ See designer’s website: http://www.bendawson.com/rbs.html.

${ }^{x}$ Evidence of the way that the RBS campus infiltrated popular consciousness as a symbol of the bank's power can be found in the novel Exit Music by Ian Rankin (Orion Books, 2007), set in 
Edinburgh and featuring Rankin's detective, John Rebus. Part of the plot concerns the relationship between the Scottish parliament and the fictional 'First Albannach Bank' (FAB), 'one of the biggest employers - and probably the most profitable company - in Scotland'. FAB has a 'brand-new corporate HQ... a city in miniature, complete with shopping arcade and cafés' (61). Later in the novel, two police officers visit the HQ ('not a building, a machine') (p253). Interestingly, the fictional campus includes a nine-hole golf-course, whereas the RBS failed in its attempt to buy out the members of the neighbouring Gogar course.

${ }^{\text {xixi }}$ Goodwin was briefly employed as an 'international consultant' by architects RMJM after leaving RBS. RMJM later went into receivership (see http://www.scotsman.com/lifestyle/arts/visual-arts/therise-and-fall-of-scottish-architects-rmjm-1-2873222).

xii Executive Director Johnny Cameron explained to investment analysts in 2007 that RBS had not done due diligence on ABN Amro: 'We have got a lot of knowledge in the organisation, quite a few people have been through ABN AMRO for example and joined us or know ABN AMRO well, it's remarkable how much you can gain from external analysis around the world, gossiping in the Hong Kong bars or whatever it might be' (see http://www.investors.rbs.com/ /media/Files/R/RBSIR/corporate-actions/acquisition-of-abn-amro-in-2007/4pm-290507-call-transcript.pdf).

xiii Playing on the 'Fawlty Towers' British TV comedy series set in a chaotically run hotel. The eponymous owner of the hotel, Basil Fawlty, was played by John Cleese. 